\title{
Three new species of Asparagus (Asparagaceae) from South Africa, with notes on other taxa
}

\author{
S.M. BURROWS* and J.E. BURROWS*
}

Keywords: Asparagaceae, Asparagus L., South Africa, taxonomy

\section{ABSTRACT}

\begin{abstract}
Three new species of Asparagus L. are described from South Africa: Asparagus elephantinus S.M.Burrows, $A$. hirsutus S.M.Burrows and A. sylvicola S.M.Burrows; and the past confusion between Asparagus acocksii Jessop and A. lynetteae (Oberm.) Fellingham \& N.L.Mey. is discussed.
\end{abstract}

\section{INTRODUCTION}

Species within the genus Asparagus are notoriously difficult to identify. The plants are unappealing to collect, and when collected, not enough attention is paid to the plant's habit, and especially the rooting system. In many instances not enough material is collected, making the identification of the plants difficult. During extensive field research and herbarium work for a taxonomic revision of the genus in southem Africa, a number of undescribed taxa have been noted, and the distribution of several species has been extended. Type localities have been revisited wherever possible, and material has been collected from the type locality or as close to the locality as possible for each taxon. This has been done to ensure that the correct concept of the taxa is understood.

Since the Buffelskloof Herbarium has yet to attain an international herbarium acronym, the temporary abbreviation $\mathrm{BNRH}$ will be used throughout.

Asparagus elephantinus S.M.Burrows, sp. nov., A. densiflori similis sed caulis longissimis validis, ramis ramulisque longis, tuberibus rotundis vel late ellipsoideis, spinis validis, pedunculo infra medio articulato, fructu maiori differt.

TYPE.-Limpopo, 2430 (Pilgrim's Rest): above J.G. Strydom Tunnel, Abel Erasmus Pass, R36, Ohrigstad, (-BC), 8 January 2005, J.E. Burrow's \& Lotter 8781 (PRE, holo.; BNRH, iso.).

Scrambling, multistemmed shrub, evergreen, usually shallow-rooted, not twining, glabrous throughout. Rhizome small; roots terete, up to $8 \mathrm{~mm}$ diam. with numerous side rootlets; lateral tubers off thick main roots, round to broadly ellipsoid, $30-51 \times 22-40 \mathrm{~mm}$. Stems robust, $10-15 \mathrm{~mm}$ thick, up to $3 \mathrm{~m}$ long, bright green, completely glabrous, faintly ribbed towards base. Spines large on stems, up to $20 \mathrm{~mm}$ long, smaller elsewhere, hard, sharp, straight to curved downwards, pale orange brown; present below branches, branchlets, cladode fascicles and flowers. Leaf scales on stem triangular, $1.0-5.5 \mathrm{~mm}$ long, very pale with darker median stripe,

\footnotetext{
* Buffelskloof Nature Reserve Herbarium. P.O. Box 710. 1120 Lydenburg. South Africa

MS. received: $2007-06-20$
}

margins entire, depauperate to absent on branches and branchlets. Branches spreading, up to $0.6 \mathrm{~m}$ long, faintly papillose-ribbed. Branchlets spreading, up to $150 \mathrm{~mm}$ long, distinctly papillose-ribbed, 5-angled, slightly zigzagging. Cladodes 1-3(-6) per fascicle, held at an angle to branches, flattened, narrowly elliptic to linear, (5-)8 $25(-31) \times 1.5-2.0 \mathrm{~mm}$ long, bright green, glossy, base constricted with a basal foot, margins papillose. Racemes 50-70 mm long, arising from branch or branchlet nodes, simple or branched, an occasional cladode sometimes present. Flowers 1-3 per fascicle, sweetly scented. Pedicel 1.5-3.0 mm long, articulated in lower half. Tepals $6,3.0-4.2 \times 1.5-1.9 \mathrm{~mm}$, apex curved inwards, margin entire. Stamens 6; filaments $2.25-2.65 \mathrm{~mm}$ long, fused length $0.75 \mathrm{~mm}$, free length $1.5-1.9 \mathrm{~mm}$; anthers orange. Style $0.4-0.5 \mathrm{~mm}$ long; stigma 3-fid, arms $0.1-0.2 \mathrm{~mm}$ long. Ovary oblong-ellipsoid, trilocular, 1.8-3.0 $\times 1.1-$ $2.0 \mathrm{~mm}$. Fruit a berry, 2- or 3-lobed, 10-14 mm diam., glabrous, red when ripe. All measurements of cladodes, leaf scales, flowering and fruiting parts taken from pickled specimens. Flowering time: January to February. Figure 1.

Distribution and habitat: Asparagus elephantinus is currently known from the Olifants River Valley of Limpopo Province, from Penge to the Abel Erasmus Pass (Figure 2), where it occurs mainly on dolomite or the quartzitic outcrops adjacent to the dolomite formations. This very robust plant, with $3 \mathrm{~m}$ long stems, grows on rocky ledges, or among rocks in leaf litter. It is principally confined to vegetation type SVcb 25, Poung Dolomite Mountain Bushveld (Mucina \& Rutherford 2006). This asparagus is widespread in its area, and is well protected since it favours rocky ledges and inaccessible cliff faces. It is surprising that such a large species of Asparagus has remained undetected for so long in such a well-visited area as the Abel Erasmus Pass.

Diagnostic characters and affinities: Asparagus elephantinus is similar to $A$. densiflorus (Kunth) Jessop in that they both have flattened cladodes, with both the cladodes and branches clearly papillate-ribbed. However, $A$. elephantinus differs from $A$. densiflorus (Table 1 ).

Erymologv: Asparagus elephantinus is named after the Olifants River Valley, to which it is currently confined; in addition, the name highlights the large size of the plant. 


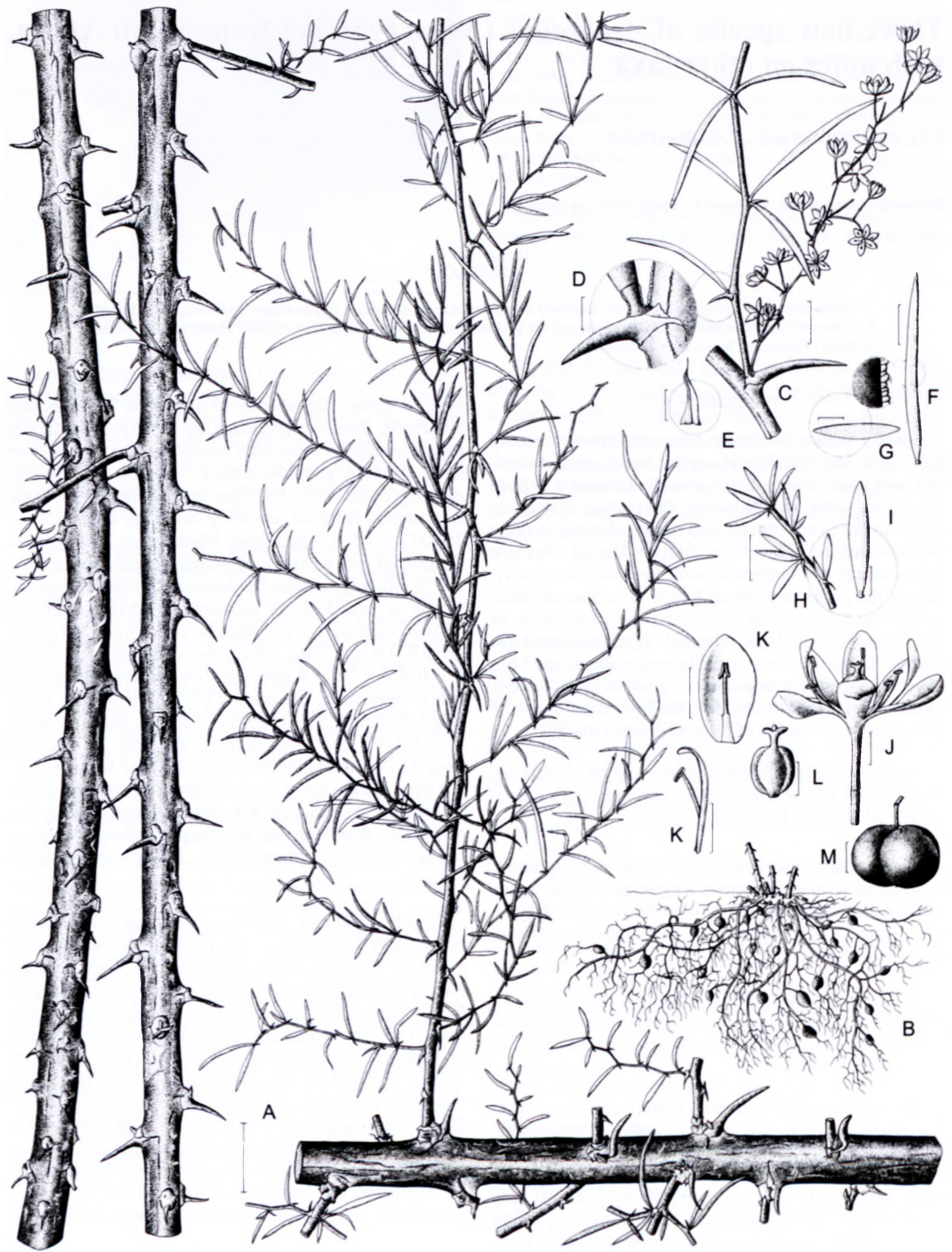

FIGURE 1-Asparagus elephantinus, A-G, J-M, JE. Burrows \& Lotter 8781; H, I, JE \& S. M Burrows 9034 . A, stem and first branch: B, rhizome habit; C, raceme; D. cladode base; E, leaf scale; F, cladode and margin enlargement; G, c/s cladode; H, I, cladodes. J-L, floral details J, flower; K, stamen and tepal; L, ovary. M. fruit. Scale bars: A, $12.2 \mathrm{~mm}$; C, F, $3.7 \mathrm{~mm} ; \mathrm{D}, 0.3 \mathrm{~mm} ; \mathrm{E}, 1.5 \mathrm{~mm} ; \mathrm{G}, 0.46 \mathrm{~mm} ; \mathrm{H}, 4.9 \mathrm{~mm}$ I, $1.2 \mathrm{~mm}$; J, K, $0.9 \mathrm{~mm}$; L, $0.6 \mathrm{~mm}$ : M, $2.4 \mathrm{~mm}$. Artist: Sandra Burrows.

Specimens examined

LIMPOPO-2430 (Pilgrim's Rest): pass W of Penge on road to Chuniespoor, $1200 \mathrm{~m}$. (-AC), 6 March 2005, J.E \& S.M. Burrows 8914 (BNRH); N bank of Olifants R. near new bridge, Penge Mine,
$800 \mathrm{~m}$. (-AD), II November 2002, J.E. Burrows \& M.C. Lotter 7878 (BNRH, PRE); $\pm 4 \mathrm{~km}$ N of Penge, next to Olifants R. $600 \mathrm{~m}$. (-AD). 13 November 2005, J.E. \& S.M. Burrows 9304 (BNRH); just above J.G. Strydom Tunnel, Abel Erasmus Pass, 679 m, (-BC), 28 August 2002, J.E \& S.M. Burrons 7770 (BNRH, PRE). 


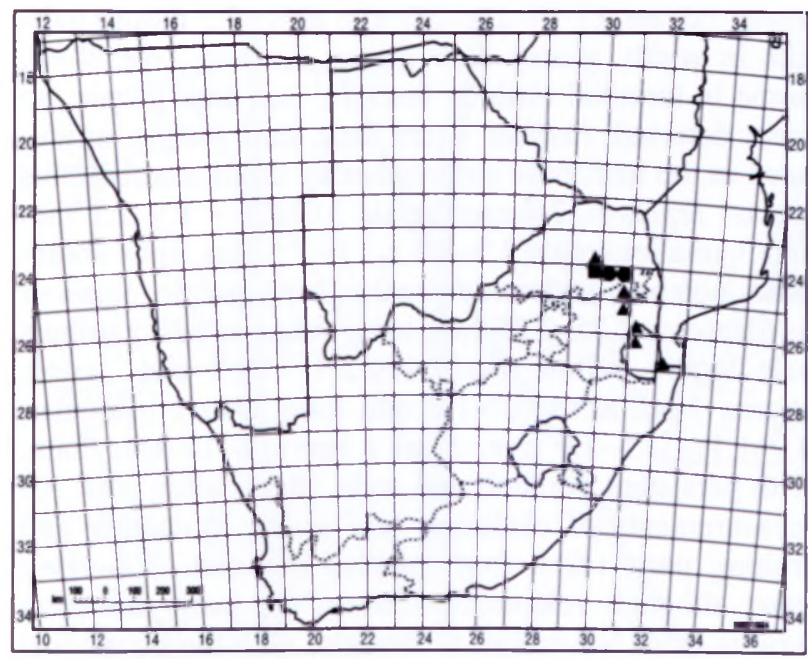

FIGURE 2.-Known distribution of Asparagus elephantinus, hirsutus, $\mathbf{\square}$; and A. sylvicola, $\mathbf{A}$

Asparagus hirsutus S.M.Burrow's, sp. nov., A. capensi var. capensi similis sed tuberibus ellipsoideis, ramis non spinescentibus, pilis omnino albis et squamis foliosis glabris differt; $A$. minutiflori similis sed pilis omnino albis, margine squamarum foliosarum integra et pedicello hirsuto in parte superiore articulato differt.

TYPE.-Limpopo, 2429 (Zebedelia): Atok Platinum Mine, Zeekoegat Farm, Monametse Village, east of mineshaft, hill slope, 816 m, (-BD), 16 November 1999 , L.M.D. Riddles 511 (PRE, holo.; BOL, BNRH,J, KEW, PRU, UNIN, iso.).

Erect, multistemmed, compact, very hairy, evergreen shrublet of foxtail form, olive to grey-green, 300-500 $\mathrm{mm}$ high. Rhizome woody; roots $0.1-5.5 \mathrm{~mm}$ diam.; with a few lateral ellipsoid tubers present, $36-40 \times 14-21$ $\mathrm{mm}$; cataphylls present. Stems $1.2-5.0 \mathrm{~mm}$ thick, faintly ribbed, pale, terete, covered in white hairs, skin peeling in patches in older specimens to smooth below. Spines 1.2-6.0 mm long, straight, thin, facing sideward or downward, hairy, only present below branch axils on main stem. Leaf scales triangular, 1.0-3.2 $\times 1.0-1.5 \mathrm{~mm}$, grey with dark blotches, becoming smaller distally, and finally disappearing. Branches 1-5, 117-134 mm long, arising in clusters from stem, curving upwards, very hairy. Branchlets absent. Cladodes (6-)8-10 in fascicle, up to 36 in terminal fascicles, clavate to linear, (1.5-)4.0-6.4 $(-10) \times 0.5 \mathrm{~mm}$ long, olive green, slightly curved, apex apiculate, $0.5 \mathrm{~mm}$ long, 6 - or 7 -angled, with simple white hairs ( $0.2 \mathrm{~mm}$ long) along angled ridges, hairs radiating out to side alternately. Flowers single, borne in cladode fascicle, no scent detected. Pedicel 0.5-2.0 mm long, articulated in top half, hairy, base surrounded by cluster of small membranous scales. Tepals 6,3 larger 2.1-2.5 $\times 1.0-1.5 \mathrm{~mm}, 3$ smaller $2-2.1 \times 0.9-1.0 \mathrm{~mm}$, white, median stripe brownish, with a ridge of hairs, apex acute, margin sometimes serrated. Stamens 6; filaments 2.6-3.5 $\mathrm{mm}$ long, fused length $1.5 \mathrm{~mm}$, free length $1.1-2.0 \mathrm{~mm}$; anthers orange. Style $1 \mathrm{~mm}$ long; stigma 3-fid, arms 0.1 $0.2 \mathrm{~mm}$ long. Ovary trilocular, $1.0-1.5 \times 1 \mathrm{~mm}$. Fruit a berry, 5-7 $\mathrm{mm}$ diam., red when ripe, with persistent perianth. All measurements of cladodes, leaf scales, flowering and fruiting parts taken from pickled material. Flowering time: September to November. Figure 3.

\section{Specimens examined}

LIMPOPO.-2429 (Zebedelia): Ga Makopane, Zeekoegat Farm 421 KS, near Atok Platinum Mine, hill slope, $850 \mathrm{~m}$, (-BD), 15 October 1997, N.H.G. Jacobsen 5540 (PRE); Zeekoegat Farm 421 KS, near Atok Platinum Mine, 850 m. (-BD), 10 November 1997 , ex cultivation, N.H.G. Jacobsen 5717 (PRE); hills above Atok Mine, Monametsi R., Sekhukhuneland, (-BD), 29 November 2005, J.E. \& S.M. Burrow' 9307 (BNRH, PRE).

Distribution and habitat: this small, extremely hairy asparagus is currently known only from the hills near the Atok Platinum Mine at Monametse in Sekhukhuneland (Figure 2). The plants grow on rocky hillsides, amongst small rocks, in full sun, or occasionally in the scant shade of the surrounding vegetation, on medium- to coarse-grained titanite-bearing tonalite (granite), in vegetation type SVcb 28, Sekhukhune Mountain Bushveld (Mucina \& Rutherford 2006). The plant is threatened and is therefore afforded VUD 1 \& 2 conservation status (D. Raimondo pers. comm. 2006).

Diagnostic characters and affinities: although Asparagus hirsutus is compared with $A$. capensis $\mathrm{L}$. var. capensis and $A$. minutiflorus (Kunth) Baker, the taxon differs significantly in the following details: $A$. hirsutus is an erect foxtail, with straight stems; the tubers are ellipsoid; the main stem is covered in white hairs; the spines are densely hairy; the leaf scales are glabrous with entire margins; the pedicel is hairy and is articulated in the top half; and the tepals have a ridge of hairs along the median stripe. A. capensis var. capensis is a muchbranched shrub up to $1.5 \mathrm{~m}$ high; tubers absent; the main stem is glabrous; the spines are sparsely hairy, becoming glabrous; the branches end in a spine; the leaf scales are hairy with a lacerate margin; the flower is sessile; and the tepals are puberulous throughout. Although $A$. minutiflorus has tubers and a foxtail growth form, the branches typically arch or sprawl along the ground. It differs from $A$. hirsutus in that the cladodes are filiform; the hairs are glandular and golden brown; the spines have a few hairs at the base; the leaf scales have lacerate margins; and the pedicel is glabrous and is articulated in the lower half.

The known distribution of $A$. hirsutus is a distinguishing character: whereas $A$. capensis var. capensis only occurs in the Cape Province and southern Namibia, $A$. minutiflorus has a wider distribution, occuring in dry areas of Mpumalanga, Limpopo, Swaziland, KwaZuluNatal and southern Mozambique.

TABLE 1.-Differences in morphology of Asparagus elephantinus and A. densiflorus

\begin{tabular}{lll}
\hline Character & A. elephantinus & A. densiflorus \\
\hline Stem length & up to $3 \mathrm{~m}$ & up to $650 \mathrm{~mm}$ \\
Branch length & up to $0.6 \mathrm{~m}$ & up to $200 \mathrm{~mm}$ \\
Branchlets & up to $150 \mathrm{~mm}$ & absent \\
Spines & $20 \mathrm{~mm}$ long. thick & $1-7 \mathrm{~mm}$ long. thin \\
Tuber & & \\
shape & broadly ellipsoid & ellipsoid \\
size & $30-51 \times 22-40 \mathrm{~mm}$ & $13-45 \times 6-22 \mathrm{~mm}$ \\
Pedicel articulation & in lower half & in middle \\
Berry & up to $14 \mathrm{~mm}$ diam. & up tol0 mm diam.
\end{tabular}



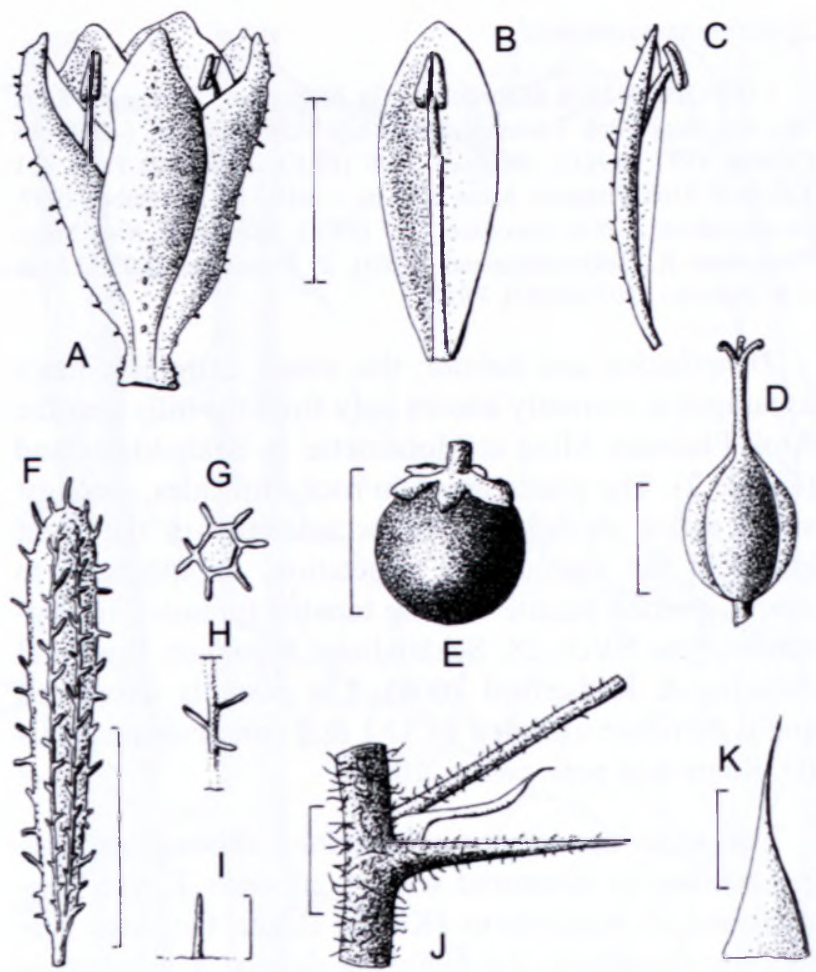

FIGURE 3.-Asparagus hirsutus, L.M.D. Riddles 5II. A-D, floral details: A, flower; B, stamen and tepal, front view; C, stamen and tepal, side view; D, ovary. E, fruit; F, cladode; G, c/s cladode; H, I, simple hairs; J, spine and leaf scale; $K$, leaf scale. Scale bars: A-C, $1.6 \mathrm{~mm}$; D, $1 \mathrm{~mm}$; E, $6.6 \mathrm{~mm}$; F, $2.2 \mathrm{~mm}$; I, 0.2 $\mathrm{mm} ; \mathrm{J}, 4.4 \mathrm{~mm} ; \mathrm{K}, 1.6 \mathrm{~mm}$. Artist: Sandra Burrows.

Etymology: Asparagus hirsutus is not easily confused with any other Asparagus species, as the extreme hairiness of the plant, (hence the specific epithet), the foxtail growth form, and its limited distribution render it unmistakeable.

Asparagus sylvicola S.M.Burrows, sp. nov., A. setacei similis sed ramulis late dispersis, cladodiis ramulisque ad angulum $90^{\circ}$ caule patentibus, tuberibus fusiformibus differt.

TYPE.-Mpumalanga, 2531 (Komatipoort): Bearded Man, Songimvelo Nature Reserve, Barberton Mtns, 1400 m, (-CB), 16 April 2005, J.E. Burrows 8931 (PRE, holo.; BNRH, iso.).

Scandent to twining, evergreen shrublet up to $3 \mathrm{~m}$ high, glabrous throughout. Rhizome creeping; roots up to $3 \mathrm{~mm}$ thick, terete, with rootlets; mature plants develop spindle-like in-line tubers, $20-100 \times 5-17$ $\mathrm{mm}$. Stems $2-4 \mathrm{~mm}$ thick, basally very finely papillateridged, dark olive green to purplish; leaf scales set on very small swellings. Spines absent throughout. Leaf scales triangular, $0.5-3.0 \times 0.5-1.0 \mathrm{~mm}$ long, dark purple to reddish brown, pale on old stems, triangular, base with small $(0.5 \mathrm{~mm})$ soft protuberance, margin entire. Branches up to $400 \times \pm 1 \mathrm{~mm}$, widely placed along stem, arising at right angles to stem, slightly zigzagging, terete, ridged. Branchlets $0.5 \mathrm{~mm}$ thick, up to 120 $\mathrm{mm}$ long, terete, widely spaced along branches, arising at right angles to branch. Secondary branchlets up to 25 $\mathrm{mm}$ long, same thickness as cladodes, arising at right angles to branchlets. Cladodes 1-9 per fascicle, filiform, terete, falcate, (5-)9-20(-28) $\mathrm{mm}$ long, $0.5 \mathrm{~mm}$ to hairlike in width, glossy dark green. Flowers 1 or $2(-4)$, borne in terminal cladode fascicle, bud dark purple, no scent detected. Pedicel $3 \mathrm{~mm}$ long, dark purple, articulated in top half, base surrounded by small membranous bracts. Tepals 6, 3 larger tepals 3.0-3.5 × 1.9-2.1 mm and 3 smaller tepals $2.5-3.0 \times 1.0-1.5 \mathrm{~mm}$, apex sometimes notched, underside streaked with purple. Stamens 6; filaments 2.75-3.25 mm long, fused at base; anthers pale lemon yellow. Style $1.8-2.5 \times 0.5 \mathrm{~mm}$, terete; stigma 3-fid, arms $0.7-1.0 \mathrm{~mm}$ long. Ovary trilocular, $0.9-1.1 \times 1.5-2.0 \mathrm{~mm}$. Fruit a berry, 6-10 mm diam. with persistent perianth and style, black when ripe. All measurements of cladodes, leaf scales, flowering and fruiting parts taken from pickled material. Flowering time: although seldom floriferous, the main flowering time is from November to January, with the occasional flower produced throughout the rest of the year. Figure 4.

Distribution and habitat: Asparagus sylvicola was first noted growing in forested areas in the Barberton Mountains in Mpumalanga and in the Lubombo Mountains in Swaziland (Figure 2). A number of specimens previously attributed to $A$. setaceus (Kunth) Oberm. are now included in this species, extending the distribution to include the forested areas of northeastern South Africa, from Haenertsberg (Limpopo) to Siteki (Swaziland). The plant is widespread in these areas, although seldom common and, since much of the remaining habitat is protected, so therefore is this species.

Diagnostic characters and affinities: Asparagus sylvicola may be confused with $A$. setaceus (Kunth) Jessop but the most distinctive difference is that the branches of $A$. sylvicola radiate out at right angles and the cladodes arise in all directions, forming a compact, springy nonaligned tangle of cladodes, whereas $A$. setaceus has its branches and cladodes arranged in a horizontal plane. The cladodes of $A$. sylvicola are falcate, and in some specimens bow-shaped, whereas the cladodes of A. setaceus are straight to slightly curved. The tubers on mature plants of $A$. sylvicola resemble small long sweetpotatoes (spindle-like), and are in-line in the main roots, whereas the tubers of $A$. setaceus are ovoid to ellipsoid and are borne laterally.

Etymology: Asparagus sylvicola ('forest dweller') is so named as it favours forest, either Scarp Forest (FOz 5 ) or the lower regions of Northern Mistbelt Forest (FOz 4), (Mucina \& Rutherford 2006).

Cultivation: Asparagus sylvicola has been cultivated as a container plant for several years, and makes a very attractive horticultural subject.

\section{Specimens examined}

LIMPOPO. - 2329 (Pietersburg): Haenertsberg. (-DD), November 1913, R. Pott 4689 (PRE).

MPUMALANGA.-2430 (Pilgrim's Rest): Mariepskop, near Klaserie Drift, (-DB), 8 April 1969, P. Vorster 616 (PRE, PRU); Mt Sheba, $1700 \mathrm{~m}$, (-DC), 2 October 1986, Deall 2165 (PRE!). 2530 (Lydenburg): Ceylon Forest Reserve, 'Jantjiesbos', I 350 m. (-BA), 7 October 1986, Deall 2193 (PRE). 2531 (Komatipoort): Kaalnug road, Malelane Dist., $350 \mathrm{~m}$. ( CB), 6 February 2003, J.E. \& S.M. Burrows 


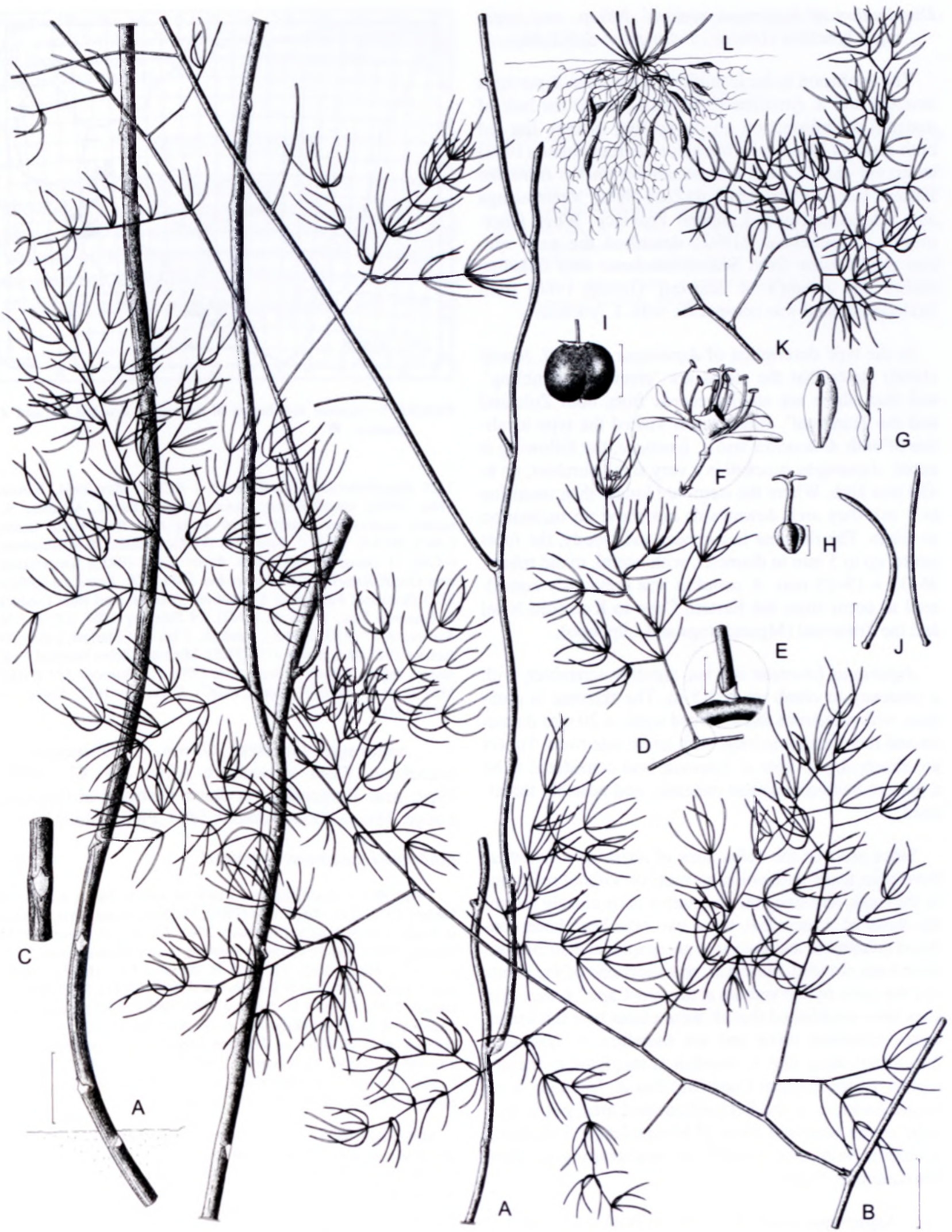

FIGURE 4.-Asparagus sylvicola, J.E. Burrows 8931 . A C, K, stem and branch; D, flowering branchlet; E, leaf scale. F-H, flower details: F. flower: G, front and side view of tepal and stamen; H, ovary. I, fruit: J, cladodes: L. thizome habit. Scale bars: A-D, $11.8 \mathrm{~mm}$; E, $5.3 \mathrm{~mm}$ F. G, I mm; H, $1.8 \mathrm{~mm}$;, $3.5 \mathrm{~mm} ;$ J. 2.9 mm; K, $5.9 \mathrm{~mm}$. Artist: Sandra Burrows.

7975 (BNRH); Ida Doya Reserve. Barberton Mins. ( CB). M.C. Lotrer s.n. (BNRH): Barberton Mtns, Pedlar's Bush, I $280 \mathrm{~m}$. (-CC), 29 October 2006. J.E. \& S. M. Burrows 9559 (BNRH. PRE); Barberton. Pedlar's Bush, 1 100-1 500 m. (-CC), January 1996. T.L. Morgenthal s.n. (PRE, PUC); Barberton. ( CC), June 1907, Thorncroft s.n. (Herh T.l. Mus. 4349 in PRE).
SWAZILAND - 2631 (Mbabane): Malagwane Hill. Mbabane, $3570^{\prime}$ [1 088 m]. (-AA), 22 June 1961. Ben Dlamini s.n. (PRE. SNDH); ibid., 22 June 1961, B. Dlamini s.n. (PRE, SNHD); ibid.. 4 May 1961. B. Dlamini s.n., (PRE, SRGH). 2632 (Bela Vista): Mtibhlati River. Lubombo Muns, Siteki area, 340 m. (-CA), 22 November 2002. J.E. \& S.M. Burrows 7895 (BNRH). 